\title{
ECONOMIC ASPECTS OF INCREASING VALUE AND SCOPE OF SHARED SERVICES CENTRES
}

\author{
Rima Tamošiūnienė ${ }^{1}$, Anna Kislovska ${ }^{2}$, Eglè Kazlauskiené ${ }^{3}$, Tsvetelina Gankova ${ }^{4}$ \\ ${ }^{1,3}$ Department of Finance Engineering, Faculty of Business Management, Vilnius Gediminas Technical University, \\ Sauletekio av. 11, Vilnius, Lithuania \\ 1, 2, ${ }^{3}$ Institute of Economics and Business, Mykolas Romeris University, Ateities str. 20, Vilnius, Lithuania \\ ${ }^{4}$ Faculty of Economics, Gabrovo Technical University, H. Dimitar str. 4, Gabrovo, Bulgaria \\ E-mails: 'rima.tamosiuniene@vgtu.lt (corresponding author); 2annavgtu@yahoo.com; \\ 3egle.kazlauskiene@vgtu.lt; ${ }^{4}$ gankova@tugab.bg
}

\begin{abstract}
Development of Business Services Market and shift from manufacturing to services economy, where customer-oriented solutions, innovation and global networks are key valuables, forced appearance of business forms such as Shared Services Centres (SSC), which are paralleled with Business Process Outsourcing, Global Business Services. This business proved its advantage in private and public sector and increased in value and scope. SSCs are seen as economic catalyst, competitive business solution of organizations with entrepreneurial mindset. SSCs accelerate economic multiplier, which is seen in internal organizational aspects and external economic aspects. The aim of this paper is to escalate economic aspects of increasing value and scope of SSC's.
\end{abstract}

Keywords: services economy, business services market, market drivers, value and scope of shared services centres, economic multiplier effect.

JEL Classification: O14; L20; D46; F23.

\section{Introduction}

Constantly changing global economy conditions, high level of technology development, force organizations to re-think their operational models and to follow hypercompetition rules, according to which innovation, customer-oriented decisions, effectiveness, simplicity, speed and cost reduction are the core values. Leaders with specific entrepreneurial mindset try to find new solutions how to compete in the global market and how to reorganize the organizational behaviour actions according to the best practice, which lead to better, faster, cheaper and competitive delivery. Such innovative decisions creates value for customer, organization and consequently the outcome of such actions is being treated as economic catalyst, which contribute to economy development.

Due to the widely discussed shift from manufacturing economy to service economy on a global scale and putting strong emphasis on increasing Business Services market contribution to states economy, changes in Business Services market is the important topic for both researchers and practitioners. The important trend in this market is transfering of business services to Shared Services Centres (SSC), which are located in more attractive economic regions, which are usually characterized by lower operational costs, cheaper, but highly educated and multilingual labor force. This shift from common to shared services should be seen not just change in business form oriented to derive economies of scale and effectiveness of organizations, but also as a strong impact on states economy both for country-of-origin and for the host country.

Therefore, SSC general concept can be seen as new topic in business management and not just as idea, but mostly as a trend of agile organization working in complex and international business environment.

However, implementing SSC is complex enterprise transformation and end-to-end integration, which involves variety of changes and these changes affect organization in different ways from front office to back office and strategic organizational level. These effects have different characteristics, which must be evaluated, and strong leadership of such implementation is essential to succeed. Supporting model of implementation and managing already implemented SSC would have huge scientific importance and would help to increase the success rate of such organizational transformations.

The aim of this scientific paper is to escalate economic aspects of increasing value and scope of SSC's. The objectives of this paper are: 
To analyze the main Business Services market trends enhancing the need of research on SSC;

To present theoretical concept and implications of SSC's;

To analyze main transformations in SSC market, which influence the increasing value and scope of SSC's;

To reveal economic aspects related to increase of value and scope of SSC.

Research methods: scientific literature analysis, comparative analysis, questionnaire, graphical visualization.

\section{Business services market trends}

By the early 1990s, it was becoming apparent that the investment was rapidly shifting from manufacturing to services. The boom in manufacturing investments was coming to an end in the developed economies and was being replaced by "front and back" office service functions (Sauvant et al. 2010). By the mid-1990s services accounted for almost two-thirds of world Gross Domestic Product (GDP), up from about half in the 1980s (World Bank 2015). The global Business Services market is estimated to exceed $€ 3.5$ trillion and to have doubled in size in the last decade (Herbert, Paraskevas 2012). It is strongly competing with manufacturing sector and exceeds manufacturing sector almost twice counting around $70.0 \%$ of world GDP (see Fig. 1).

Business Services accounts significant part of the whole state economy (see Fig. 2) and have grown faster than the overall economy. For instance even in the relative European economy, between 1999-2009 the average growth rate for Business Services was $2.38 \%$, while the average for all sectors of the EU economy was 1.1\% (European Commission 2014).

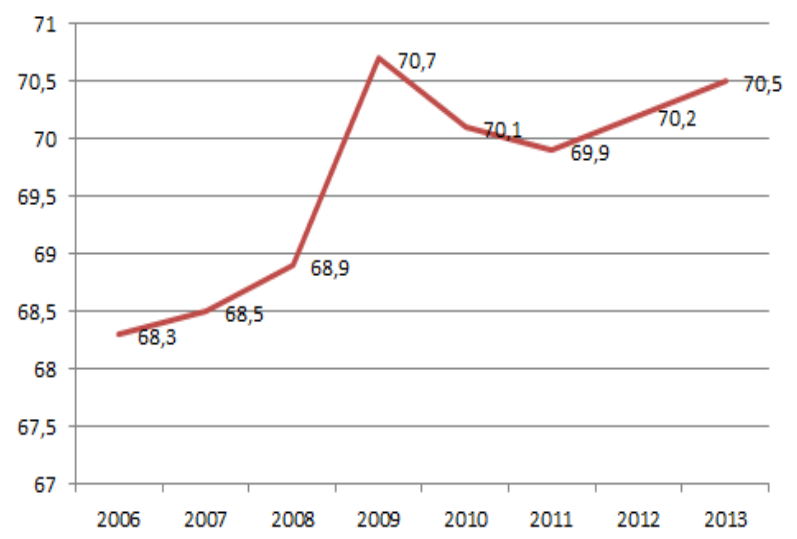

Fig. 1. World services value added (\% of GDP) (Source: World Bank 2015)

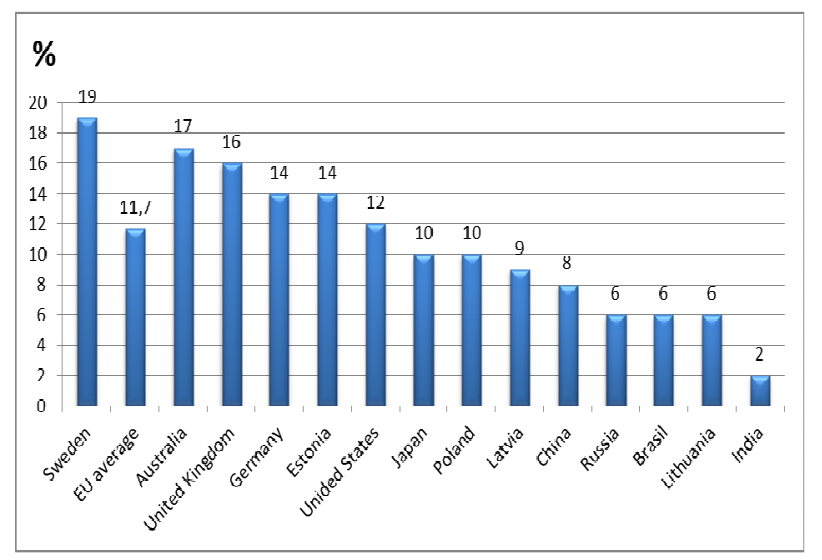

Fig. 2. Business services part of economy (Source: Herbert, Paraskevas 2012)

Deloitte (2015a) stresses that there are certain ongoing and disruptive market drivers for Business Services. Skills shortage, globalization, data analytics, technology cost pressures, mobility, mergers and acquisitions activities and socio-economic trends are seen as ongoing market drivers, which can lead to the development of Business Services Market. However, such political aspects as elections, taxation, legislation and regulations suspend the development of this market. Therefore, ongoing market drivers are accelerated by the organizations themselves and disruptive market drivers can be influenced by the companies, but mostly depends on the political factors. This should be taken into consideration when developing the strategy for economic growth enhancement in Business Services and attracting foreign investors.

European Commission (2014) emphasizes the changing context of Business Services. The shift to services requires business model innovation. Business models should shift from products to solutions, from outputs to outcomes, from transactions to relationships, from suppliers to network partners, from elements to ecosystems (European Commission 2014). This innovative approach should be also incorporated in the strategic developments of the countries.

Lithuanian SSC market has streadily grown since 2008 and it is among the most attractive destinations for shared services and business process outsourcing (Cushman \& Wakefield 2015). However, there researches on SSC implementation effects, managing of existing SSC and their impact on organizational efficiency are too fragmentary. Usually they emphasize the reasons and advantages of implementing SCC.

In the light of these insights, SSC is a good example of innovative business model, which can 
take advantage of using the ongoing market drivers and following the main shift in Business Services.

\section{Theoretical concept and implications of shared services centres}

In research literature, different terms for the shared services concept are used - „shared services", „shared service orginazation“, „shared services model“, „shared services centres“, „,business services centres" and these terms are also being paralleled with Business Process Outsourcing (BPO) and Global Business Services GBS (see Table 1).

Table 1. SSC, BPO and GBS Connections (Source: compiled by the authors)

\footnotetext{
SSC the concentration of company resources performing like activities, typically spread across the organization, in order to service multiple internal partners at lower cost and with higher service levels, with the common goal of delighting external customers and enhancing corporate value (Schulman et al 1999);

separate organizational unit with a focus on internal customers or organizational arrangement for providing services to a group of public or private sector clients via a service provider which replaces the previous in-house or contracted-out function (Miles 2011); model, which should include a collection of shared services whose characteristics are determined by the customers, provided within an intra-organizational business arrangement, to a specific set of end-users, by a semiautonomous or autonomous business unit (service provider) on the basis of agreed conditions (Bondarouk 2014);

the consolidation of administrative or support functions (such as human resources, finance, information technology, supply chain, and customer service) from several departments or agencies into a single, stand-alone organizational entity whose only mission is to provide services as efficiently and effectively as possible (Accenture Federal Services 2015; Fersht, Brown 2014).

BPO the provision by a third party of defined services and activities (regardless of geographic location), via a multi-year contract (PwC 2014).
}

GBS combination of both shared services and outsourcing as well as optimized processes and technology, performance management and governance (PwC 2014).
It is a relatively new way of organizing backoffice functions, which is being implemented across companies worldwide. This novelty has taken over as the most discussed topic in the last fifteen years and it is likely to stay with us for some time to come (Rudzioniene, Sakalauskiene 2014).

It is worth to stress that SSC conception fits both private services and public services providers needs. According to Dubinas, Smilga (2009), Miles (2011), Civinskas, Dvorak (2011), McIvor et al. (2011), Civinskas, Laurušonytè (2012), Paagman (2015) SSC approach constitutes the „new age" of public sector management. Accenture Federal Services (2015) emphasize that while cost-cutting may be the initial rationale, highperformance public sector organizations focus more on using the potential of shared services to improve mission or citizen services. It is the argument that SSC can be seen as economic catalyst implemented both in creative and technologyoriented commercial organizations and public institutions, which regulate business (Dubinas, Smilga 2009).

Therefore, such service delivery model has proved its effectiveness and various forms of SSC have increased in popularity ( $\mathrm{PwC} 2015)$.

Another important element in SSC definition is the internationalization approach, which is mostly suitable for business organizations. Together with the evolution of internationalization theories new business forms such as SSC appeared in international markets and global mindset, geographical and technology proximity are the factors that encourage to look for more attractive locations for SSC establishment (see Fig. 3).

What is more, new technology such as robotics, higher productivity, other costs such as energy, transportation, currency, capital, government imposed costs (tariffs, regulation) are also placing downward pressure on the price of labor as a percentage of service costs and moving up the agenda within SSC and BPO sector (Cushman \& Wakefield 2015; Herbert, Seal 2012). Both the wider economic and political context should be evaluated during the SSC location selection process.

All in all, micro and macro factors on firm, country and wider geographical level should be taken in consideration during the analysis of SSC's ant their implications. 


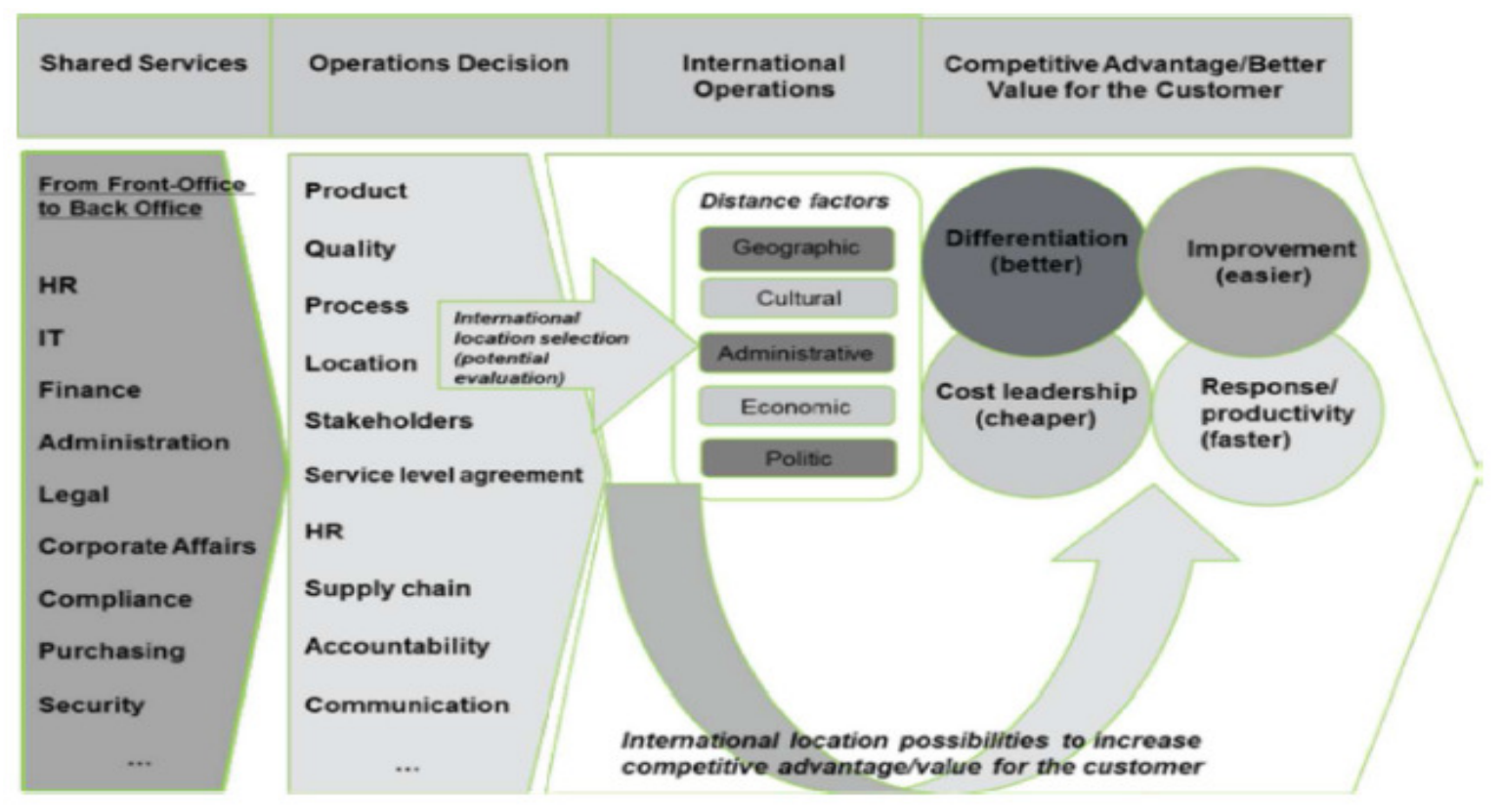

Fig. 3. Shared services and international location (Source: Tamošiūnienè, Kislovska 2015)

\section{Transformations in shared services centres market - increasing value and scope}

SSC market should react to global economy conditions and adopt business decisions to the changing fundamentals of the world.

The BPO and SSC industry is constantly growing by over $5 \%$ each year despite the fact that this industry is still undergoing significant change and developments due to effects of the global recession. This sector should continually look for new ways to gain competitive advantage in marketplace (Cushman \& Wakefield 2015).

From the prospective of development of market needs, SSC's forms transformed from local to multinational, from specialized to multifunctional and from cost-saving to efficiency and value seeking. What is more, SSC definition parallels with BPO and GBS can be seen as one of the significant signs of increasing scope of SSC and constantly changing limits of such organizational form.

Authors distinguish two main features in SSC's reaction to transformation to market needs and their development path (see Fig. 4):

Increasing value of SSC's;

Increasing scope of SSC's.

From value prospective - there is a clear transition from cost-saving organizational model to customer-oriented smart and intelligent organizational solution. SSC's distinctive feature is looking for ways to improve in services they currently provide and in new services they would like to offer (Accenture... 2011). Value that SSCs create has increased from basic economies of scale through standardization and resources re-allocation to customer centric, innovative, continuously improving efficiency organizational model. Therefore, there is a clear transformation from business process (service) standartisation to business process reengineering.

From scope prospective - service portfolio provided by SSC is constantly increasing. Despite the fact that primary goal of sharing business operations was reducing costs through standardization and consolidation of transactional processes, which are rarely seen as strategically important or close to external customers, management continue to focus on the basics, but also asking for more to facilitate the transition into higher value-added activities such as customer support, forecasting, reporting or treasury into existing SSC's (BearingPoint 2011; Deloitte 2015b; Rothwell et al. 2011). Therefore, the increasing scope of SSC's also proves the increased value that SSCs bring as management rely on such organizational model and experience shows that SSC's excellence can be also used for more sophisticated processes, which create more value for organization. 


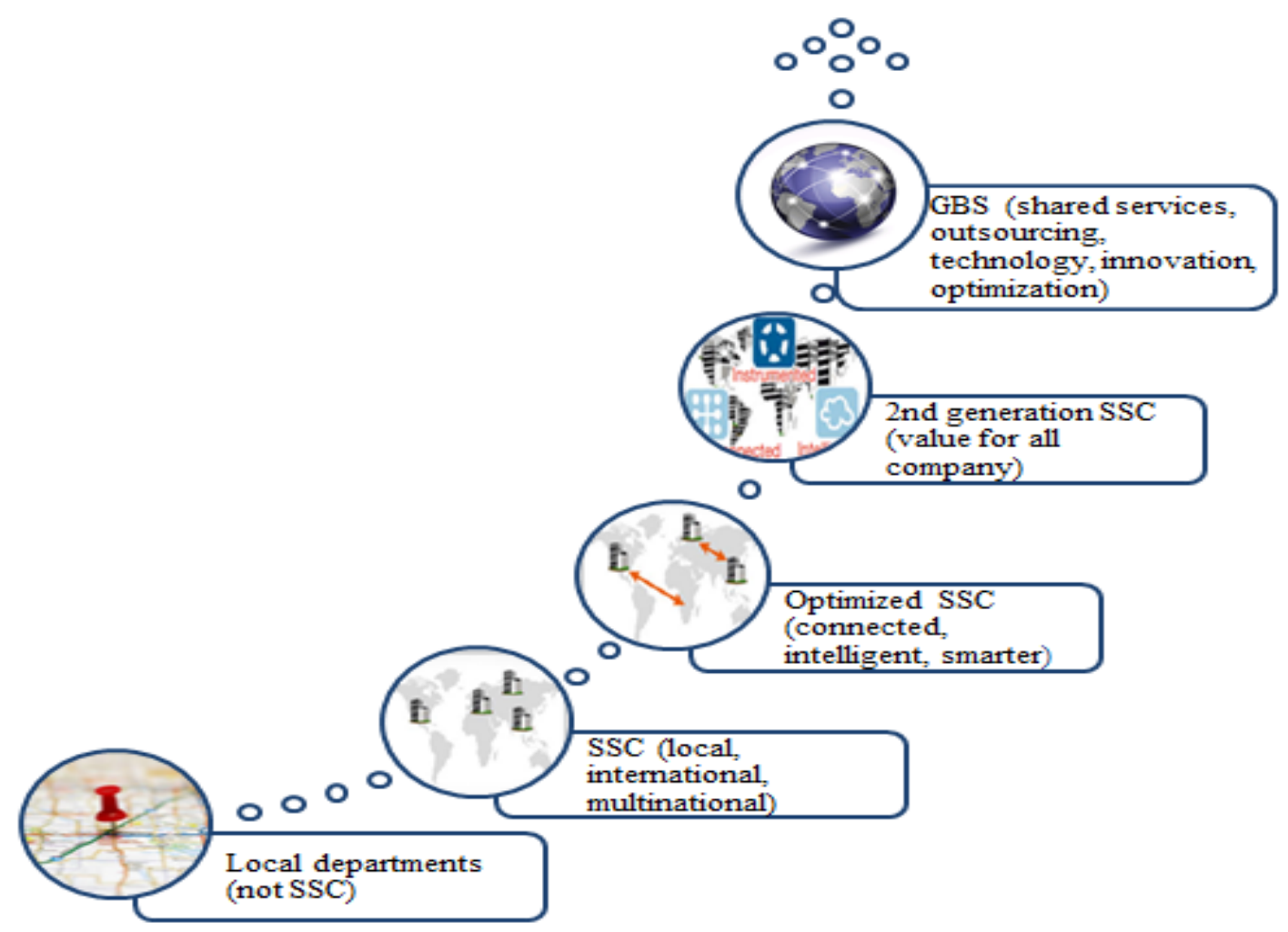

Fig. 4. Evolution path of SSC (Source: compiled by the authors)

\section{Economic aspects of increased value and scope of shared services centres}

Increased value and scope of SSCs increase the potential impact on state economy in different ways. In result of more sophisticated processes performed by SSC there is a need to (see Fig. 5): increase the level of processes knowledge of SSC employees;

increase the number of languanges known in $\mathrm{SSC}$;

strengthen different skills needed to cover high-value added processes in SSC;

increase the number of collaborative activities within the organization;

increase the wages due to higher qualification and responsibility level;

strenghtened employer branding;

expand the premises and secondary services used by SSC and employees (printing, scanning, postal, cleaning, catering, transportation and other services);

increased spendings of employees due to higher wages (increased consumption);

other changes.

The increased need for the changes described above and other changes is an example of multiplier effect. Multiplier effects are one of the fundamental mechanisms of local and regional develop- ment and occur when one type of economic activity affects another (Domański, Gwosdz 2010). Possible impact of increased scope and value of SSC on economy of host country is presented in the figure below. However, there is also economic impact on country-of-origin, which is not presented, but obvious. Authors can include such impacts as higher competition for market players, who have not invested in SSC yet, cross-country career and travelling opportunities for the employees as well as some negative factors of re-allocation of work to another country in result of which there are less working places for country-of-origin employees.

According to the authors, SSC itself as well as public, educational institutions and other parties, who take place in economic life of the state contribute to the positive effect of SSC implementations, scope and value increasement on economy of host country. The more interactions there are, the more visible the impact can be:

Value marketing - the information about SSCs as business model, their conception and goals, impact on economy through the view of multiplier effect should be spreaded and escalated on different levels - from internal gatherings to external partners such as educational institutions, governamental organizations etc. 


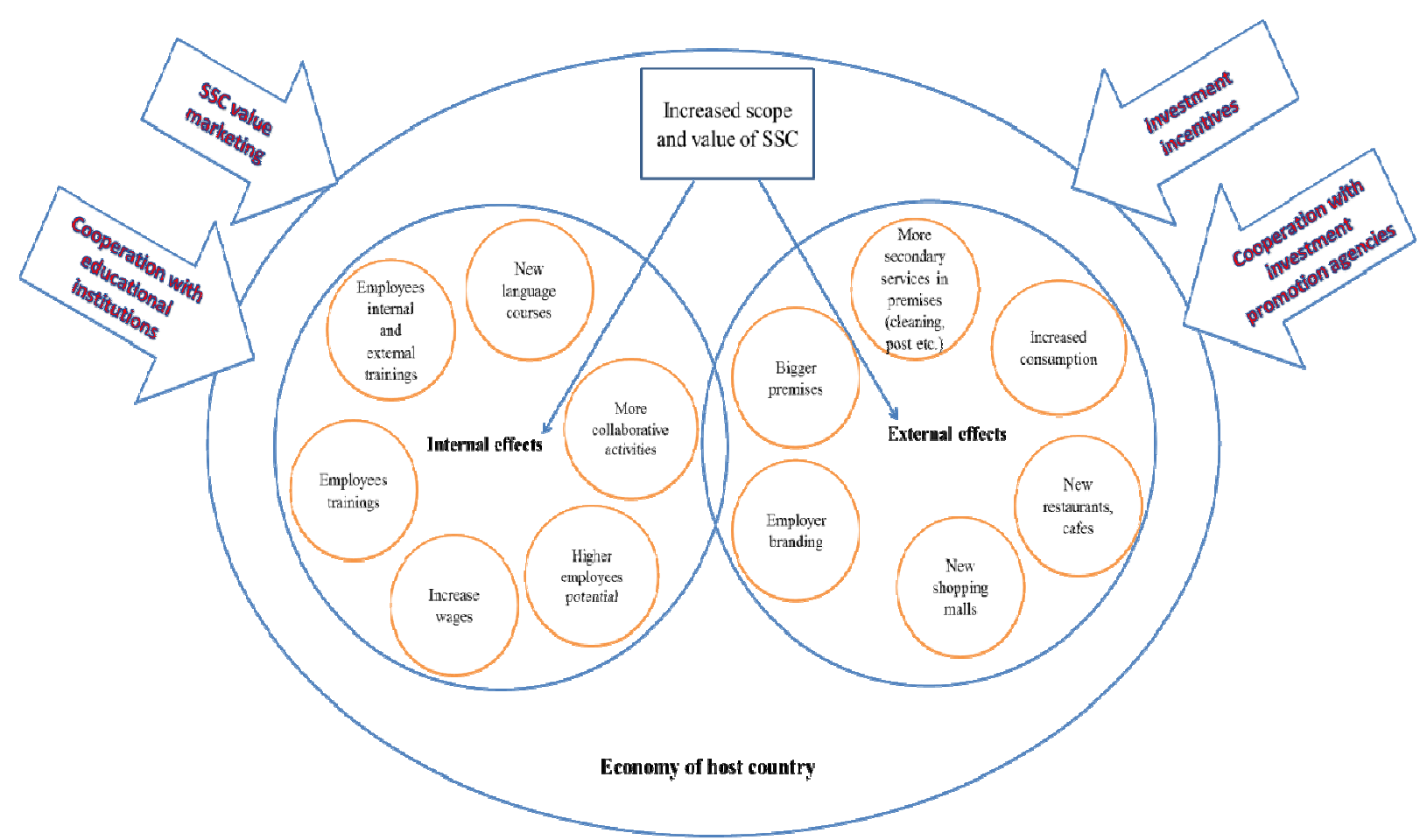

Fig. 5. Host country economic effects related to increased scope and value of SSC (Source: compiled by the authors)

Cooperation with educational institutions business and educational institutions partnership is valuable for both parties as SSC can identify the valuable young specialists and educational institutions gain practical knowledge and can offer attractive studies posibilities for the students. In the end, multiplier effect is stronger due to this outcome.

Investment incentives related to financial support for newly establishing SSCs, possibilities to reduce the taxable profit and other investment incentives is accelerator for economy as they play the key role for investors, who choose the loaction for investment.

Cooperation with investment promotion agencies - they have established number of connections in business and public sector and can play important intermediary role. That is especially important when investor comes to new market. What is more, in the other stages od SSC development, it can be important aspects of SSCs branding, it builds trustable relationships withon the country and forces faster multiplier effect to the economy of host country.

Therefore, the increasing value and scope of SSC plays important role in the state economic development. SSC implementation provides number of oportunities on different level - from organizational level to economic level. Wider view of
SSC impact on economy should be evaluated to explore those opportunities.

\section{Conclusions}

The shift from manufacturing to services economy forces organizations to re-think their business strategies, to react to the recent Business Services Market trends and look for new business models opportunities.

Changing context of Business Services and the development of Business Services Market is affected by both ongoing and disruptive market drivers. Disruptive market drivers such as political decisions, regulations, taxation should not suspend the development of this market. Therefore, dialog between business and public sector is very important.

SSC, which is also being paralleled with BPO and GBS, is increasing in popularity due to innovative, customer-oriented approach of handling the back-office functions in more effective way and on a global scale. SSC concept is being implemented across companies worldwide, it is being defined as one of the economic catalysts, which has proved its advantages both in private and public sectors.

The BPO and SSC industry is constantly growing and this business form has changed from local to global and from cost-saving to efficiency 
and value seeking. Two main features in SSC's reaction to transformation to market needs and their development path distinguished by authors are increasing value and increasing scope of SSC. Increased value and scope of SSC increase the potential impact on state economy and should be evaluated from micro to macro prospectives on both organizational and state economy level.

In result of wider services portfolio of SSC and more sophisticated services provided by them, this business model accelerates the multiplier effect and especially positive economic impact on economy of host country. The economy of host country is being affected throught the internal organizational aspects (new knowlege, trainings, languages, cross-country collaboration, increased wages etc.) and the external economic aspects (more secondary services due to increase in premises, opportunities for new market players as restaurants, cafes, shopping malls near the premises due to increased consumption, new possibilities for branding of SSC).

According to authors, SSC value marketing, business and educational institutions cooperation, investment incentives and cooperation with investment promoting agencies would enhance the positive economic effects of SSC implementations.

\section{References}

Accenture Federal Services. 2015. High performance outcomes: Government shared services [online], [cited...]. Available from Internet:

https://www.accenture.com/t20150929T041550_w_ /u s-en/_acnmedia/Accenture/Conversion-Assets/ DotCom/Documents/Global/PDF/Dualpub_22/ Accenture-High-Performance-OutcomesGovernment-Shared-Services.pdf

Accenture Research Report. 2011. Trends in shared services: unlocking the full potential [online], [cited 15 July 2015]. Available from Internet:

http://www.accenture.com/SiteCollectionDocuments/P DF/Accenture-Trends-in-Shared-Services.pdf

BearingPoint GmbH, Frankfurt/Main (2011). Shared Services Industry Specifics and Trends in the European FS Market. Shared Services in Financial Services Survey [online], [cited 15 July 2015]. Available from Internet:

http://www.bearingpoint.com/en-n1/7-1595/sharedservices-industry-specifics-and-trends-in-theeuropean-fs-market $/ ? \& \mathrm{p}=610$

Bondarouk, T. 2014. Shared services as a new organizational form. Emerald Group Publishing Limited. ISBN: 978-1-78350-535-7. ISSN: 1877:6361 (Series).
Civinskas, R.; Dvorak, J. 2011. Viešujų paslaugų teikimo centru steigimo galimybès Lietuvoje, Tiltai 4(57): 77-93. ISSN 1392-3137.

Civinskas, R.; Laurušonyte, E. 2012. Viešujuc paslaugu tobulinimas: jungtinių paslaugu centrų steigimas, Journal of Management 1(20). ISSN 1648-7974.

Cushman \& Wakefield. 2015. Where in the world? Business Process Outsourcing and shared Service Location Index [online], [cited 05 December 2015]. Available from Internet:

http://www.cushmanwakefield.com/ /media/globalreports/Where $\% 20 \mathrm{In} \% 20$ The $\% 20$ World_Business $\% 20$ Process\%20Outsourcing_low_2015.pdf

Deloitte. 2015a. Business Services Outlook 2015. A Deloitte Insight Report [online], [cited 06 December 2015]. Available from Internet:

http://www2.deloitte.com/content/dam/Deloitte/uk/Doc uments/bps/deloitte-uk-business-servicesoutolook-2015.pdf

Deloitte. 2015b. 2015 Global shared services survey: Executive summary [online], [cited 10 December 2015]. Available from Internet:

https://www2.deloitte.com/content/dam/Deloitte/gl obal/Documents/Process-and-Operations/gx-2015ss-survey-interactive-030415.pdf

Domański, B.; Gwosdz, K. 2010. Multiplier effects in local and regional development, Quaestiones Geographicae 29(2): 27-37. http://dx.doi.org/10.2478/v10117-010-0012-7

Dubinas, V.; Smilga, E. 2009. Katalizatoriaus koncepcijos panaudojimas, didinant strateginio valdymo efektyvuma Lietuvoje. Organizaciju vadyba: sisteminiai tyrimai $\mathrm{Nr} .50$.

European Commision. 2014. High-level group on business services. Ref. Ares(2014)1095851 08/04/2014 [online], [cited 25 November 2015]. Available from Internet:

file://C:/Users/INspiron1/Downloads/A4_HLGBS report 2014_web\%20(2).pdf

Fersht, P.; Brown, D. J. 2014. Executive report: The State of Services \& Outsourcing in 2014. HfS Research in Conjunction with KPMG [online], [cited. 15 December 2015]. Available from Internet: https:/www.kpmg-institutes.com/content/dam/ kpmg/sharedservicesoutsourcinginstitute/pdf/2014/ state-of-outsourcing-2014-exec-findings-hfs.pdf

Herbert, I. P.; Seal, W. B. 2012. Shared Services as a new organisational form: Some implications for management accounting, The British Account Review 44(2): 83-97. http://dx.doi.org/10.1016/j.bar.2012.03.006

Herbert, R.; Paraskevas, C. 2012. The business services sector: calculating the market size. Lloyds Bank.

McIvor, R.; McCracken, M.; McHug, M. 2011. Creating outsourced shared services arrangements: Lessons from the public sector, European Management Journal 29(6): 448-461. http://dx.doi.org/10.1016/j.emj.2011.06.001 
Miles, T. 2011. Applying shared services to public sector property and facilities asset management, in IET and IAM Asset Management Conference, November 30-December 1 2011, Lodon, Great Britain. http://www.crossref.org/iPage?doi=10.1049 \%2Fcp.2011.0561

Paagman, A. 2015. An integrative literature review and empirical validation of motives for introducing shared services in government organizations, International Journal of Information Management 35(1): 110-123.

http://dx.doi.org/10.1016/j.ijinfomgt.2014.10.006

PwC. 2014. Shared service centres. Study from $7^{\text {th }}$ February 2014. Personal access to information.

PwC. 2015. Central and Eastern Europe (CEE) by By Paul Stewart, Managing Partner. Shared service centres in Central and Eastern Europe - Moving up the value curve. Personal access to information.

Rothwell, A. T.; Herbert, I. P.; Seal, W. 2011. Shared service centers and professional employability, Journal of Vocational Behavior 79(1): 241-252. http://dx.doi.org/10.1016/j.jvb.2011.01.001
Rudzioniene, K.; Sakalauskiene, R. 2014. Shared service center factors and return on investment, Social Sciences 83(1): 55-62.

Sauvant, K. P.; McAllister, G.; Maschek, W. A. 2010. Foreign direct investments from emerging markets: the challenges ahead. New York: Palgrave Macmillan. http://dx.doi.org/10.1057/9780230112025

Schulman, D. S.; Harmer, M. J.; Dunleavy, J. R.; Lusk, J. S. 1999. Shared services: Adding value to the business units. New York, NY: Wiley.

Tamošiūnienè, R. Kislovska, A. 2015. Shared services impact on organizational effectiveness, in Management and Engineering'15: XIII international scientific conference: scientific proceedings, Vol. I, June 21-24 2015, Sozopol, Bulgaria. ISSN 1310-3946.

World Bank. 2015. World Bank national accounts data, and OECD National Accounts data files. [online], [cited 05 December 2015]. Available from Internet: http://data.worldbank.org/indicator/NY.GDP. MKTP.KD.ZG?page $=5$ 